\title{
Viscosity of egg white from hens of different strains fed with commercial and natural additives
}

\author{
Viscosidade da clara de ovo proveniente de poedeiras de diferentes espécies com aditivos comerciais e naturais
}

Fernanda Papa SPADA ${ }^{1}$, Érika Maria Roel GUTIERREZ ${ }^{2}$, Miriam Coelho de SOUZA ${ }^{2}$, Solange Guidolin Canniatti BRAZACA ${ }^{1 *}$, Dayane Elizabeth Aoqui LEMES $^{2}$, Flávia Salgado FISCHER ${ }^{2}$, Antonio Augusto Domingos COELHO ${ }^{3}$, Vicente José Maria SAVINO ${ }^{3}$

\begin{abstract}
Yolk color and egg white (albumen) cleanliness and viscosity are important parameters by which consumers judge the quality of eggs. This study aimed to investigate changes in albumen viscosity during storage of eggs for up to 36 days from two different commercial laying hen strains (Carijo Barbada and Isa Brown) fed a diet containing annatto (1.5 and 2.0\%) or a synthetic additive without synthetic colorants (control). Analyses of humidity, albumen height, $\mathrm{pH}$, viscosity, foam formation, and stability were carried out on eggs. Carijo Barbada strain had smaller albumen, lower humidity and higher egg white viscosity than Isa Brown strain; however, with storage, viscosity lowered significantly on both strains. Initially, the addition of $2.0 \%$ of annatto or a synthetic additive increased viscosity in both strains, but with storage only the control maintained longer viscosity. Lower viscosity did not change foam density and stability.

Keywords: strain; egg; foam formation; foam stability; $\mathrm{pH}$; albumen height.
\end{abstract}

\section{Resumo}

A coloração da gema, transparência e viscosidade da clara (albúmen) são parâmetros importantes que os consumidores consideram na avaliação dos ovos. O objetivo do estudo foi verificar as trocas que ocorrem na armazenagem por 36 dias em relação à viscosidade da clara de ovos produzidos por poedeiras de duas diferentes linhagens (Carijo Barbada eIsa Brown ), as quais receberam dietas contendo urucum (1,5 e 2,0\%) ou aditivo sintético. Foram realizadas as análises de umidade, altura do albúmen, pH, viscosidade, formação e estabilidade da espuma. A linhagem Carijó Barbada apresentou menor quantidade de albúmen, menor umidade e maior viscosidade que a linhagem Isa Brown, entretanto, com a estocagem, a viscosidade diminuiu significativamente para ambas as linhagens. Inicialmente, a adição de $2,0 \%$ de urucum ou aditivo sintético foi suficiente para aumentar a viscosidade em ovos obtidos de ambas as linhagens, mas com a estocagem, somente o controle manteve maior viscosidade. A baixa viscosidade não interferiu na densidade e estabilidade da espuma.

Palavras-chave: linhagens; ovo; formação de espuma; estabilidade da espuma; pH; altura do albúmen.

\section{Introduction}

An important factor for the consumer acceptability of eggs is the color of the yolk (intensity and uniformity) and chicken skin, which can be controlled by the diet of egg-laying hens (HARDER et al., 2007; CARVALHO et al., 2006). Different synthetic colorants based on ether apocarotene (yellow) and canthaxanthin (red) and natural colorants such as annatto (Bixa orellana) have been used to reach this goal (BOCANEGRA; OSORIO; RONDON, 2004; BISCARO; CANNIATTIBRAZACA, 2006).

Eggs consist of 8 to $11 \%$ shell, 56 to $61 \%$ of albumen, and 27 to $32 \%$ of yolk (ROSE, 1997). The albumen surrounds the yolk and its function is to absorb impact, and it is a source of nutrients. The albumen consists of a liquid layer surrounding the yolk, a dense intermediate layer, and an outer layer next to the shell, which has a similar composition to the innermost layer. Most of the water present in the egg is stored in the albumen, representing $88 \%$ of its contents.

The albumen is a solution of proteins, and the ovomucin represents $54 \%$ of the total content; ovalbumin, conalbumin, ovomucoide, lysozyme, globulin, and avidin are also present in the albumen (ORDÓNEZ, 2005). There is only about $1 \%$ carbohydrate in the albumen, and the content of fat is between 0.1 and $0.2 \%$. The yolk gains water from albumen during the egg storage period, and its contents may vary in moisture from 46 to $59 \%$ depending on the duration and storage conditions (ORDÓNEZ, 2005).

Various attributes of quality of the albumen and yolk are lost with prolonged egg storage. The internal quality of the egg 
changes immediately after laying due to factors such as loss of water (weight loss) and $\mathrm{CO}_{2}$ through the shell, liquefaction of albumen, movement of liquids between compartments, distension and flaccidity of the viteline yolk membrane, which could break (LUCISANO et al., 1996). The albumen viscosity is a quality variable linked to the albumen functional characteristics such as whipping, emulsifying, and gelling proprieties among others (KEMPS et al., 2010).

The reduction in viscosity values cause albumen thinning and, which can directly affect the shelf life of eggs (CANER; CANSIZ, 2008).

This study aimed to investigate changes in albumen viscosity during storage of eggs for up to 36 days from two different commercial laying hen strains fed a diet containing annatto ( 1.5 and $2.0 \%$ ) or a synthetic additive without synthetic colorants (control).

\section{Materials and methods}

The experiment was conducted at the School of Agriculture "Luiz de Queiroz", University of São Paulo (ESALQ/USP) and at the Methodist University of Piracicaba (UNIMEP), at Lins.

About 80 egg-laying hens from the Carijó Barbara strain and 80 from a commercial strain, Isa Brown, of an egg-laying age around 35 weeks were used in this study. The hens went through a two week adjustment period being fed with the same commercial diet.

The hens were then divided into eight groups of 20 hens each and fed daily with basic diet containing: a) 1.5 or $2.0 \%$ annatto (in natura) grounded ( $2.0 \mathrm{~mm}$ sieve) with maize starch (as an inert substance) according to Harder et al. (2007); or b) artificial additive formulated with $0.001 \%$ of carophyll yellow, and $0.006 \%$ of carophyll red, (i.e., 10 and $60 \mathrm{~g}$ of the additive per ton of feed) according to Garcia et al. (2002); or c) without additive/colorant (control).

The hens were housed in suitable cages with continuous fresh water supply. The feeding was provided strictly at the same time every day in order to promote regular growth, and the eggs were collected daily after feeding.

It was used an 18-week of age ration for poultry as basic diet consisting of lime, soybean meal, wheat bran, corn grain (68.98\%), vegetable oil, vitamin mineral premix, amino acids, and protenose.

The treatments were administered at the beginning of the $35^{\text {th }}$ week to $37^{\text {th }}$ week of age, when the eggs were collected and optimum stability of the yolk color had been achieved (HARDER et al., 2007). However, the color analysis was only initiated after 30 days of consumption.

\subsection{Determination of water content in egg}

The water content in the egg was carried out in fresh eggs and in eggs stored for up to 36 days, according to Association of Official Analytical Chemists (1997).

\subsection{Determination of the albumen height and $p H$}

The height of the albumen was measured using a micrometer in the middle of the thick albumen equidistant from the outer edge of the albumen and the yolk since this region is perpendicular to the chalazae (SPARKS, 1994; SECHINATO; ALBUQUERQUE; NAKADA, 2006).

Albumen $\mathrm{pH}$ was measured immediately after the measurement of the height of albumen and yolk using a calibrated $\mathrm{pH}$ meter.

\subsection{Determination of viscosity}

Three eggs from each treatment and storage period (fresh, 14, 28 , and 36 days of storage) were used in the viscosity measurement. About $8 \mathrm{~mL}$ of albumen were collected from each egg, and 10 readings were made using a Brookfield Engineering model $\mathrm{LV}$ viscometer with spindle SC4-18-30 rpm, at rates of 39, $6(1 / \mathrm{s})$.

\subsection{Formation and stability of the foam}

The foam volume was measured according to Griswold (1962). A $75 \mathrm{~mL}$ albumen sample from 3 treatment and different storage period eggs (freshly laid eggs or incubated for 14, 28, and 36 days) were collected. The foam was prepared at the highest speed and constant rotation mixing for 7 minutes. The foam specific gravity was determined compressing the foam into a container and levelled with a spatula. The specific gravity was found by dividing the foam weight by the weight of equal volume of water. The higher foam volume, the smaller is its weight and the lower is its specific gravity. The stability of the foam was determined using $15 \mathrm{~g}$ of foam poured into each three funnels placed into a burette, and thus it was possible to measure the volume of egg-white displaced from each funnel.

\subsection{Statistical analysis}

The study design was entirely random, and the average difference between the strains and the diets was determined statistically using the $\mathrm{F}$ test and Tukey test at $5 \%$ level. These tests were analyzed using Statistical Analysis System Institute (1999).

Foam stability statistical analysis was presented in two different ways: a) the total volume detached after 120 minutes; and b) with average volumes displaced every 15 minutes from 8 readings made during 120 minutes of observation.

\section{Results and discussion}

Table 1 shows water content in the egg according to baseline (fresh egg) and after 36 days of storage. Water content in eggs was not different between diets and at baseline (fresh eggs) and at 36 days of storage. However, when comparing hens' strains and baseline to 36 days of storage, a statistical significant difference was observed. Isa Brown strain showed higher water content than Carijó Barbada's, and each diet also showed significant difference comparing baseline to 36 days of storage. Isa Brown strain showed higher water content values then Carijó Barbada's, possibly due to higher proportion of albumin in their eggs (ROSE, 1997). After 36 days of storage, all eggs from both strains lost significantly their water content compared to baseline (Table 1).

\subsection{Albumen height determination}

Table 2 shows the average albumen height from different strains and diets at several periods of storage. Diet did not show 
Table 1. Percentage of water content in egg according to strains and diet at baseline (fresh egg) and 36 days of storage.

\begin{tabular}{lcc}
\hline \multicolumn{1}{c}{ Strains } & Baseline & 36 days \\
\hline Carijó Barbada & $74.68 \pm 1.3^{\text {xby }}$ & $71.83 \pm 0.8^{\mathrm{bB}}$ \\
Isa Brown & $77.14 \pm 0.8^{\mathrm{aA}}$ & $74.42 \pm 2.5^{\mathrm{aB}}$ \\
\hline \multicolumn{1}{c}{ Diets } & \\
\hline Control & $76.02 \pm 1.5^{\mathrm{aA}}$ & $73.62 \pm 2.5^{\mathrm{aB}}$ \\
Additive & $75.89 \pm 1.8^{\mathrm{aA}}$ & $73.26 \pm 1.8^{\mathrm{aB}}$ \\
$1.5 \%$ & $75.70 \pm 1.7^{\mathrm{aA}}$ & $71.69 \pm 2.3^{\mathrm{aB}}$ \\
$2.0 \%$ & $76.03 \pm 1.8^{\mathrm{aA}}$ & $73.93 \pm 1.9^{\mathrm{aB}}$ \\
\hline
\end{tabular}

${ }^{x}$ Mean \pm standard deviation. ${ }^{y}$ Different lowercase letters in vertical indicate difference between strains or diets, by Tukey $(\mathrm{p} \leq 0.05)$. ${ }^{2}$ Different uppercase letters in horizontal indicate difference between time of storage, by Tukey $(\mathrm{p} \leq 0.05)$.

any difference in albumen height (Table 2); however, Isa-Brown strain had higher albumen height than Carijo strain at baseline $(\mathrm{p}>0.05)$, but not at any other period of storage.

Roberts and Choct (2006) also found changes in the albumen height when comparing the addition of different enzymes to the diet of different strains of laying hens. Their values were higher than those presented in Table 2, ranging from 6.4 to $9.2 \mathrm{~mm}$. Silversides and Scott (2001) also found a significant decrease in albumen height throughout 10 days.

Storage decreases albumen height possibly due to egg-white liquefaction and consequent loss of height (Table 2). Li-Chan and Nakai (1989), and Robinson (1987) and Toussant and Latshaw (1999) reviewed the chemistry of albumen quality and reported that ovalbumin, ovotransferrin, ovomucoid, ovomucin, lysozyme, and globulins make up approximately $90 \%$ of the albumen protein, and ovomucin is the most important in determining the height of the inner thick albumen. Isolated ovomucin is extremely viscous, and it has excellent foaming properties when combined with other proteins (JOHNSON; ZABIK, 1981). It is not clear from the scientific literature that moderate differences in albumen height are associated with altered functional characteristics of the egg (SILVERSIDES; SCOTT, 2001).

\subsection{Yolk and albumen pH}

Table 3 shows no change in yolk pH for both strains Carijó Barbada and Isa Brown at long term storage up to 36 days. $\mathrm{pH}$ values for yolk is around 6 as described by Mano, Baptista and Moraes (2007) and agreed with yolk pH found in the study.

Table 4 shows an increase in albumen $\mathrm{pH}$ of fresh eggs (baseline) compared to that of the eggs stored for 14 to 28 days and a decrease compared to that of eggs stored for 36 days for both strains and diets. The results show a high albumen $\mathrm{pH}$ variation with storage; however, there was no direct relationship observed after 14 days of storage. Silversides and Scott (2001) reported a $\mathrm{pH}$ variation in Isa Brown strain albumen throughout 10 days of storage from 7.43 (in fresh eggs) to 9.32 (10 days storage). The data in Table 4 showed a higher value for fresh eggs (baseline) and a similar value after 14 days of storage comparing to Silversides and Scott (2001) throughout 10 days of storage.

Albumen $\mathrm{pH}$ increase is a phenomenon reported in the literature (POWRIE, 1977; BURLEY; VADEHRA, 1989) and is
Table 2. Albumen height (in millimeters) for each strain and diet at baseline, 14, 28, and 36 days of storage.

\begin{tabular}{lcccc}
\hline \multicolumn{1}{c}{ Strains } & Baseline & 14 days & 28 days & 36 days \\
\hline Carijo Barbada & $5.48 \pm 1.2^{\mathrm{xbyAz}}$ & $2.24 \pm 1.2^{\mathrm{aB}}$ & $1.25 \pm 0.8^{\mathrm{aC}}$ & $1.13 \pm 0.6^{\mathrm{aC}}$ \\
Isa Brown & $6.04 \pm 1.3^{\mathrm{aA}}$ & $2.02 \pm 0.7^{\mathrm{aB}}$ & $1.12 \pm 0.4^{\mathrm{aC}}$ & $0.96 \pm 0.4^{\mathrm{aC}}$ \\
\hline \multicolumn{1}{c}{ Diets } & & & & \\
\hline Control & $5.61 \pm 1.0^{\mathrm{aA}}$ & $2.19 \pm 1.0^{\mathrm{aB}}$ & $1.15 \pm 0.4^{\mathrm{aC}}$ & $1.10 \pm 0.5^{\mathrm{aC}}$ \\
Additive & $5.61 \pm 1.2^{\mathrm{aA}}$ & $1.94 \pm 0.6^{\mathrm{aB}}$ & $1.17 \pm 0.4^{\mathrm{aC}}$ & $1.01 \pm 0.5^{\mathrm{aC}}$ \\
$1.5 \%$ & $5.90 \pm 1.6^{\mathrm{aA}}$ & $2.02 \pm 0.7^{\mathrm{aB}}$ & $1.36 \pm 1.0^{\mathrm{aBC}}$ & $1.13 \pm 0.6^{\mathrm{aC}}$ \\
$2.0 \%$ & $5.91 \pm 1.2^{\mathrm{aA}}$ & $2.36 \pm 1.4^{\mathrm{aB}}$ & $1.07 \pm 0.5^{\mathrm{aC}}$ & $0.95 \pm 0.4^{\mathrm{aC}}$ \\
\hline
\end{tabular}

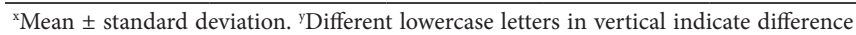
between strains or diets, by Tukey $(\mathrm{p} \leq 0.05)$. ${ }^{2}$ Different uppercase letters in horizontal indicate difference between time of storage, by Tukey $(\mathrm{p} \leq 0.05)$.

Table 3. Yolk pH for Carijó Barbada and Isa Brown strains and experimental diets at baseline, 14, 28 and 36 days of storage.

\begin{tabular}{lcccc}
\hline \multicolumn{1}{c}{ Strains } & Baseline & 14 days & 28 days & 36 days \\
\hline Carijo Barbada & $6.23 \pm 0.1^{\mathrm{xayA}}$ & $6.33 \pm 0.1^{\mathrm{aA}}$ & $6.50 \pm 0.2^{\mathrm{aA}}$ & $6.51 \pm 0.3^{\mathrm{aA}}$ \\
Isa Brown & $6.19 \pm 0.1^{\mathrm{aA}}$ & $6.37 \pm 0.2^{\mathrm{aA}}$ & $6.80 \pm 0.4^{\mathrm{aA}}$ & $6.54 \pm 0.2^{\mathrm{aA}}$ \\
\hline \multicolumn{1}{c}{ Diets } & & & & \\
\hline Control & $6.25 \pm 0.1^{\mathrm{aA}}$ & $6.37 \pm 0.1^{\mathrm{aA}}$ & $6.50 \pm 0.2^{\mathrm{aA}}$ & $6.55 \pm 0.3^{\mathrm{aA}}$ \\
Additive & $6.19 \pm 0.1^{\mathrm{aA}}$ & $6.41 \pm 0.1^{\mathrm{aA}}$ & $6.81 \pm 0.4^{\mathrm{aA}}$ & $6.49 \pm 0.2^{\mathrm{aA}}$ \\
$1.5 \%$ & $6.18 \pm 0.1^{\mathrm{aA}}$ & $6.39 \pm 0.2^{\mathrm{aA}}$ & $6.90 \pm 0.3^{\mathrm{aA}}$ & $6.49 \pm 0.1^{\mathrm{aA}}$ \\
$2.0 \%$ & $6.22 \pm 0.1^{\mathrm{aA}}$ & $6.24 \pm 0.1^{\mathrm{aA}}$ & $6.37 \pm 0.0^{\mathrm{aA}}$ & $6.57 \pm 0.5^{\mathrm{aA}}$ \\
\hline
\end{tabular}

${ }^{{ }^{x} M e a n} \pm$ standard deviation. ${ }^{\mathrm{y}}$ Different lowercase letters in vertical indicate difference between strains or diets, by Tukey $(\mathrm{p} \leq 0.05) .{ }^{2}$ Different uppercase letters in horizontal indicate difference between time of storage, by Tukey $(\mathrm{p} \leq 0.05)$.

Table 4. Albumen pH for Carijó Barbada and Isa Brown strain and experimental diets at baseline, 14, 28, and 36 days of storage.

\begin{tabular}{llccc}
\hline \multicolumn{1}{c}{ Strains } & \multicolumn{1}{c}{ Baseline } & 14 days & 28 days & 36 days \\
\hline Carijo Barbada & $8.93 \pm 0.0^{\mathrm{aaC} C z}$ & $9.05 \pm 0.0^{\mathrm{aB}}$ & $9.39 \pm 0.1^{\mathrm{aA}}$ & $9.17 \pm 0.0^{\mathrm{aAB}}$ \\
Isa Brown & $8.76 \pm 0.1^{\mathrm{bB}}$ & $9.29 \pm 0.3^{\mathrm{aA}}$ & $9.72 \pm 0.6^{\mathrm{aA}}$ & $9.15 \pm 0.0^{\mathrm{aA}}$ \\
\hline \multicolumn{1}{c}{ Diets } & & & \\
\hline Control & $8.92 \pm 0.0^{\mathrm{aC}}$ & $9.31 \pm 0.0^{\mathrm{aA}}$ & $9.35 \pm 0.0^{\mathrm{aA}}$ & $9.17 \pm 0.0^{\mathrm{aB}}$ \\
Additive & $8.83 \pm 0.2^{\mathrm{aD}}$ & $9.31 \pm 0.0^{\mathrm{aB}}$ & $9.40 \pm 0.1^{\mathrm{aA}}$ & $9.17 \pm 0.0^{\mathrm{aC}}$ \\
$1.5 \%$ & $8.83 \pm 0.1^{\mathrm{aC}}$ & $8.87 \pm 0.7^{\mathrm{aBC}}$ & $10.01 \pm 0.8^{\mathrm{aA}}$ & $9.16 \pm 0.0^{\mathrm{aB}}$ \\
$2.0 \%$ & $8.81 \pm 0.2^{\mathrm{aD}}$ & $9.21 \pm 0.1^{\mathrm{aB}}$ & $9.47 \pm 0.2^{\mathrm{aA}}$ & $9.14 \pm 0.0^{\mathrm{aC}}$ \\
\hline
\end{tabular}

${ }^{x}$ Mean \pm standard deviation. ${ }^{y}$ Different lowercase letters in vertical indicate difference between strains or diets, by Tukey $(\mathrm{p} \leq 0.05)$. ${ }^{2}$ Different uppercase letters in horizontal indicate difference between time of storage, by Tukey $(\mathrm{p} \leq 0.05)$.

related to water evaporation and egg $\mathrm{CO}_{2}$ loss during storage, which reduces albumen thickness and the vitelline membrane weakening the surround of the yolk (LUCISANO et al., 1996).

The liquefaction of albumen due to the increase in $\mathrm{pH}$ is influenced by the ovomucina-lysozyna complex. This complex is stabilized by electrostatic connections that are responsible for higher viscosity of the albumen in fresh eggs (KATO; IMOTO; YAGISHITA, 1975).

\subsection{Viscosity}

Table 5 presents the average viscosity value obtained for baseline (fresh egg) and for each storage period and each strain and diet. 
Table 5. Viscosity for strains and diets at baseline, 14, 28, and 36 days of storage.

\begin{tabular}{lcccc}
\hline \multicolumn{1}{c}{ Strains } & Baseline & 14 days & 28 days & 36 days \\
\hline Carijo Barbada & $18.70 \pm 6.3^{\text {xayA }}$ & $13.68 \pm 7.7^{\mathrm{aB}}$ & $12.12 \pm 1.9^{\mathrm{aB}}$ & $10.89 \pm 1.8^{\mathrm{aB}}$ \\
Isa Brown & $17.42 \pm 6.1^{\mathrm{aA}}$ & $14.99 \pm 2.9^{\mathrm{aB}}$ & $11.96 \pm 2.0^{\mathrm{aB}}$ & $9.75 \pm 1.6^{\mathrm{bB}}$ \\
\hline \multicolumn{1}{c}{ Diets } & & & \\
\hline Control & $16.15 \pm 6.9^{\mathrm{bA}}$ & $16.42 \pm 10.8^{\mathrm{aA}}$ & $13.14 \pm 2.7^{\mathrm{aA}}$ & $12.31 \pm 2.4^{\mathrm{aA}}$ \\
Additive & $19.93 \pm 5.9^{\mathrm{aA}}$ & $11.98 \pm 3.8^{\mathrm{bB}}$ & $11.36 \pm 1.5^{\mathrm{bB}}$ & $9.82 \pm 2.5^{\mathrm{bB}}$ \\
$1.5 \%$ & $14.31 \pm 4.4^{\mathrm{bA}}$ & $14.99 \pm 3.0^{\mathrm{aA}}$ & $10.02 \pm 1.5^{\mathrm{cB}}$ & $9.00 \pm 1.9^{\mathrm{bB}}$ \\
$2.0 \%$ & $21.83 \pm 8.8^{\mathrm{aA}}$ & $13.97 \pm 2.5^{\mathrm{abB}}$ & $13.65 \pm 1.7^{\mathrm{aB}}$ & $9.87 \pm 1.8^{\mathrm{bC}}$ \\
\hline
\end{tabular}

${ }^{x}$ Mean \pm standard deviation. ${ }^{y}$ Different lowercase letters in vertical indicate difference between strains or diets, by Tukey $(\mathrm{p} \leq 0.05)$. ${ }^{2}$ Different uppercase letters in horizontal indicate difference between time of storage, by Tukey $(\mathrm{p} \leq 0.05)$.

Egg viscosity decreased with time in both strains. When analyzing the difference between the strains, statistical difference was observed only $(\mathrm{p} \leq 0.05)$ at 36 days of storage (Table 5). When comparing the storage periods within the same strain, a statistical difference was observed for fresh eggs with all other storage periods, but no significant difference was found between periods.

Lucisano et al. (1996) also found a decreased viscosity with increased storage time and reported that it might be due to an increase in the flow behavior index over temperature, which was an indicative of a transition from pseudoplasticity to newtonity.

The albumen viscosity depends on ovomucin-lysozyme complex (KATO; IMOTO; YAGISHITA, 1975), and the concentration of ovomucin is four times higher in thick albumen compared to liquefied albumen (BURLEY; VADEHRA, 1989). When lysozyme is present in the complex, it becomes stronger and its destabilization is due to $\mathrm{pH}$ increase during storage (KATO; IMOTO; YAGISHITA, 1975; SEIBEL, 2005). The higher water content found in Isa Brown strain may explain the lower viscosity found in this strain (Table 1).

Comparing the diets (Table 5), a statistical difference between the viscosity values of fresh eggs can be observed. The highest value was found for the diet containing $2 \%$ of annatto and artificial carotenoids. However, during storage, the control was more stable than the other diets, and after 36 days of storage it showed higher viscosity.

Chang and Chen (2000) carried out a study that applied various methods and parameters to assess the effect of changes in albumen $\mathrm{pH}$ and its functional properties. They reported that the ovomucin-lysozyme complex has probably an important role in reducing the viscosity. However, it does not explain the relationship between carotenoids and viscosity loss. Similarly, Shenga, Singh and Yadav (2010) showed a significant decrease in the viscosity of egg albumen in both control and thermally treated eggs, and they reported that during subsequent storage a faster rate of liquefaction of thickness was observed for both raw and pasteurized eggs. No changes foam stability and density were found either; even with a decrease in viscosity. Kemps et al. (2010) also concluded that rheological properties of albumen were not useful indexes for albumen freshness due to natural variations among fresh eggs after lay.

\section{Conclusion}

Carijo Barbada strain had smaller albumen, lower humidity and higher yolk viscosity then Isa-brown strain. However, with storage, viscosity lowered significantly in both strains. Initially, the addition of $2 \%$ of annatto or synthetic additive was enough to increase viscosity in both strains, but with storage, only the control maintained longer viscosity. Lower viscosity did not change foam density and stability.

\section{References}

ASSOCIATION OF OFFICIAL ANALYTICAL CHEMISTS - AOAC. Official methods of analysis of AOAC International. 16. ed. Maryland: AOAC, 1997. v. 2.

BISCARO, L. M.; CANNIATTI- BRAZACA, S. G. Cor, beta-caroteno, e colesterol em gema de ovos obtidos de poedeiras que receberam diferentes dietas. Ciência e Agrotecnologia, v. 30, n. 6, p. 1130-1134, 2006. http:// dx.doi.org/10.1590/S1413-70542006000600014

BOCANEGRA, E. S.; OSORIO X. O.; RONDON, E. O. O. Evaluation of xanthophylls extracted from Tagetes erectus (Marigold Flower) and Capsicum Sp. (Red Pepper Paprika) as a pigment for egg-yolks campare with synthetic pigments. International Journal of Poultry Science, v. 11, n. 3, p. 685-689, 2004. http://dx.doi.org/10.3923/ijps.2004.685.689

BURLEY, R. W.; VADEHRA, D. V. The albumen: chemistry. In: BURLEY, R. W.; VADEHRA, D. V. (Ed.). The avian egg. New York: Wiley,1989. p. 65-128.

CANER, C.; CANSIZ, O. Chitosan coating minimises eggshell breakage and improves egg quality. Journal of the Science of Food and Agriculture, v. 8, p. 56-61, 2008. http://dx.doi.org/10.1002/jsfa.2962

CARVALHO, P. R. et al. Influência da adição de fontes marinhas de carotenóides á dieta de galinhas poedeiras na pigmentação da gema do ovo. Brazilian Journal of Veterinary Research and Animal Science, v. 43, n. 5, p. 654-663, 2006.

CHANG, Y. I.; CHEN, T. C. Functional and gel characteristics of liquid whole egg as affected by $\mathrm{pH}$ alteration. Journal of Food Engineering, v. 45, n. 4, p. 237-241, 2000. http://dx.doi.org/10.1016/ S0260-8774(00)00066-2

GARCIA, E. A. et al. Efeito dos níveis de cantanxantina na dieta e sobre o desenpenho e qualidade dos ovos de poedeiras comerciais. Revista Brasileira de Ciência Avícola, v. 4, n. 1, p. 1-7, 2002. http://dx.doi. org/10.1590/S1516-635X2002000100007

GRISWOLD, M. R. The experimental study of foods. HOUGTON MIFFLIN CO.: BOSTON, 1962. 469 p.

HARDER, M. N. C. et al. Cholesterol and iron availability in yolk of laying hens feed with annatto (Bixa orellana). Animal, v. 1, n. 1, p. 477-482, 2007. http://dx.doi.org/10.1017/S1751731107685048

JOHNSON, T. M.; ZABIK, M. E. Egg albumen proteins interactions in an angel food cake system. Journal of Food Science, v. 46, n. 4, p. 1231-1236, 1981. http://dx.doi.org/10.1111/j.1365-2621.1981. tb03029.x

KATO, A.; IMOTO, T.; YAGISHITA, K. The binding groups in ovomucinlysozyme interaction. Agricultural and Biological Chemistry, v. 39, p. 541-544, 1975. http://dx.doi.org/10.1271/bbb1961.39.541

KEMPS, B. J. et al. The assessment of viscosity measurements on the albumen of consumption eggs as an indicator for freshness. Poultry Science, v. 89, p. 2699-2703, 2010. PMid: 21076109. http://dx.doi. org/10.3382/ps.2008-00520

LI-CHAN, E.; NAKAI, S. Biochemical basis for the properties of egg white. Critical Review of Poultry Biology, v. 2, p. 21-59, 1989. 
LUCISANO, M. et al. Evalution of chemical and physical albumen characteristics during the storage of shell eggs. Journal of Agricultural and Food Chemistry, v. 44, n. 5, p. 1235-1240, 1996. http://dx.doi.org/10.1021/jf950485o

MANO, S. B.; BAPTISTA, R. F.; MORAES, I. A. Qualidade dos ovos e seus derivados. Avicultura Industrial, v. 98, n. 6, p. 48-52, 2007.

ORDÓNEZ, J. A. Ovos e produtos derivados. In: ORDÓNEZ, J. A. (Ed.). Tecnologia de alimentos: alimentos de origem animal. Porto Alegre: Artmed, 2005. p. 269-279.

POWRIE, W. D. Chemistry of eggs and egg products. In: STADELMAN, W. I.; COTTERILL, O. J. (Eds.). Egg Science \& Technology. Westport: AVI Publishing, 1977. p. 65-91.

ROBERTS, J. R.; CHOCT, M. Effects of commercial enzyme preparations on egg and eggshell quality in laying hens. British Poultry Science, v. 47, n. 4, p. 501-510, 2006. http://dx.doi. org/10.1080/00071660600834175

ROBINSON, D. S. The chemical basis of albumen quality. In: WELLS,R. G.; BELYAVIN, C. G. (Eds.). Egg quality-current problems and recent advances. London: Butterworths, 1987. p. 171-191.

ROSE, S. P. Principles of poultry science. New York: CAB international, 1997. $135 \mathrm{p}$.
SECHINATO, A. S.; ALBUQUERQUE, R.; NAKADA, S. Efeito da suplementação dietética com microminerais orgânicos na produção de galinhas poedeiras. Brazilian Journal of Veterinary Research and Animal Science, v. 43, n. 2, p. 159-166, 2006.

SHENGA, E.; SINGH, R. P.; YADAV, A. S. Effect of pasteurization of shell egg on its quality characteristics under ambient storage. Journal of Food Science Technology, v. 47, n. 4, p. 420-425, 2010. http://dx.doi.org/10.1007/s13197-010-0069-2

SILVERSIDES, F. G.; SCOTT, T. A. Effect of storage and layer age on quality of eggs from two lines of hens. Poultry Science, v. 80, n. 8, p. 1240-1245, 2001.

SEIBEL, N. F. Preservação e conservação de ovos. In: SOUZA-SOARES, L. A.; SIEWERDT, F. (Eds.). Aves e ovos. Pelotas: Editora e Gráfica Universitária, 2005. p. 91-109.

SPARKS, N. H. C. The egg: a compartmentalized, aseptically package food. In: BOARD, R. G.; FULLER, R. (Eds.). Microbiology of the avian egg. New York: Chapman \& Hall. 1994. p. 95-99.

STATISTICAL ANALYSIS SYSTEM INSTITUTE - SAS. Sas/Qc software: usage and reference. Version 8. Cary: SAS, 1999.

TOUSSANT, M. J.; LATSHAW J. D. Ovomucin content and composition in chicken eggs with different interior quality. Journal of the Science of Food and Agriculture, v. 79, n. 12, p. 1666-1670, 1999. http:// dx.doi.org/10.1002/(SICI)1097-0010 